\title{
Retroviral Gene Transfer to Primitive Normal and Leukemic Hematopoietic Cells Using Clinically Applicable Procedures
}

\author{
Philip F. D. Hughes, ** J. Dean Thacker, *\$ Donna Hogge, *\|l Heather J. Sutherland, *\|l Terry E. Thomas, * \\ Peter M. Lansdorp, ${ }^{\star \|}$ Connie J. Eaves, ${ }^{\star \star}$ and R. Keith Humphries ${ }^{\star \|}$ \\ *The Terry Fox Laboratory, B. C. Cancer Agency, Vancouver, British Columbia, V5Z 1L3 Canada; and Departments of "Medicine, \\ ${ }^{\S}$ Medical Genetics, and ${ }^{\ddagger}$ Pathology, University of British Columbia, Vancouver, British Columbia, V6T 1Z1, Canada
}

\begin{abstract}
Clinical uses of gene transfer to bone marrow transplants require the establishment of a reproducible method for infecting large numbers of very primitive hematopoietic cells at high efficiency using cell-free retrovirus-containing media. In this study we report the results of experiments with preparations of a high-titer $\left(2-5 \times 10^{7} / \mathrm{ml}\right)$ helper-free recombinant neo ${ }^{\mathrm{r}}$ retrovirus that indicate this goal can now be achieved based on measurements of gene transfer efficiencies to cells referred to as long-term culture initiating cells (LTC-IC) because they give rise to clonogenic cells after $\geq 5$ wk in long-term culture (LTC). Intermittent, repeated exposure of normal human marrow mononuclear cells to virus-containing supernatant over a 3-d period of cell maintenance on an IL-3/granulocyte colonystimulating factor (G-CSF) producing stromal layer resulted in gene transfer efficiencies to LTC-IC of $41 \%$; a level previously obtainable only using co-cultivation infection techniques. Marrow cells enriched $\geq 500$-fold for LTC-IC (1-2\% pure) by flow cytometry showed gene transfer efficiencies of $27 \%$ when infected in a similar fashion over a shorter period $(24 \mathrm{~h})$, but in the presence of added soluble IL-3 and G-CSF without stromal feeders, and this increased to $61 \%$ when Steel factor was also present during the infection period. By using a less highly enriched population of LTC-IC obtained by a bulk immunoselection technique applicable to large-scale clinical marrow harvests, gene transfer efficiencies to LTC-IC of $40 \%$ were achieved and this was increased to $60 \%$ by short-term preselection in G418. Southern analysis of DNA from the nonadherent cells produced by these LTC over a 6-wk period provided evidence of clonal evolution of LTC-IC in vitro. Leukemic chronic myelogenous leukemia LTC-IC were also infected at high efficiency using the same supernatant infection strategy with growth factor supplementation. These data demonstrate the feasibility of using cell-free virus preparations for infecting clinical marrow samples suitable for transplantation, as well as for fur-
\end{abstract}

Address reprint requests to Dr. Humphries, Terry Fox Laboratory, B. C. Cancer Research Centre, 601 West 10th Ave., Vancouver, BC V5Z 1L3, Canada.

Received for publication 25 November 1991 and in revised form 27 January 1992.

1. Abbreviations used in this paper: $\mathrm{CML}$, chronic myelogenous leukemia; LTC-IC, long-term culture initiating cell(s); NA, nonadherent; PCR, polymerase chain reaction; SCF, stem cell factor (Steel factor).

J. Clin. Invest.

(c) The American Society for Clinical Investigation, Inc.

$0021-9738 / 92 / 06 / 1817 / 08 \quad \$ 2.00$

Volume 89, June 1992, 1817-1824 ther analysis of human marrow stem cell dynamics in vitro. ( $J$. Clin. Invest. 1992. 89:1817-1824.) Key words: chronic myelogenous leukemia $\bullet$ growth factors $\bullet$ long-term culture

\section{Introduction}

Gene transfer is now widely recognized as a powerful tool for analysis of biological events and disease processes at both the cellular and molecular level. More recently the potential use of gene transfer technology for therapeutic applications has also received considerable attention. Retrovirally mediated gene transfer to human lymphocytes has recently been tested in clinical trials aimed at treating patients with genetic disease (adenosine deaminase deficiency; see reference 1 ), and protocols have been approved to use retroviral marking of bone marrow cells in the context of autologous bone marrow transplantation for malignant disease. In the latter instance, it is hoped that this approach will provide new information concerning the dynamics of marrow recovery and the origin of cells contributing to relapse. Although a variety of cell types may serve as useful targets for gene transfer in the clinical setting, extensive experience with bone marrow transplantation and progress in isolating and defining the cells likely to be responsible for permanent reconstitution of the hematopoietic system have focused interest on primitive hematopoietic cell targets.

Numerous studies documenting retroviral mediated gene transfer to murine bone marrow cells with long-term repopulating ability have now been reported (2-6). Such studies have contributed to a better understanding of the proliferative capacity of individual repopulating cells (7) and of the clonal dynamics of repopulation $(8,9)$, although reproducible, persistent expression of the transferred gene at desired levels remains a matter of concern $(10,11)$. Results with larger animals such as dogs $(12-15)$, sheep $(16)$, and nonhuman primates $(17,18)$ have been less impressive, although efficient gene transfer to hematopoietic colony-forming progenitors in these species has been obtained. Gene transfer to human hematopoietic colonyforming progenitors using retroviral vectors has also been reported by a number of groups (19-27). Exposure of the target cells to growth factors during the infection period has emerged as an important factor in both murine and human studies (21, $24,28,29)$ and, by using an infection protocol incorporating growth factor stimulation, we have recently shown that high gene transfer efficiency to a more primitive human cell type that gives rise to clonogenic progenitors after $\geq 5$ wk in longterm culture (LTC) ${ }^{1}$ can also be achieved (24). Similarly, Dick et al. (25) have demonstrated that retrovirally marked human progenitors can be detected for many weeks after transplantation of infected human marrow into immunodeficient mice. Such evidence strongly suggests that hematopoietic cells able to regenerate blood cell formation in bone marrow transplant recipients can be transduced by retroviral vectors. 
Efforts to optimize gene transfer efficiencies have concentrated primarily on infection strategies involving co-cultivation of the hematopoietic target cells with virus-producing cells. However, the advantages of this approach may be offset by a diminished recovery of the most primitive cells which are, themselves, adherent $(6,30,31)$. Moreover, the risk of viral producer cells contaminating the target cells renders such methods unsuitable for clinical applications. The present studies were undertaken to determine whether procedures could be devised that would retain high gene transfer efficiency to very primitive human hematopoietic cells (both normal and leukemic) following their exposure to cell-free medium conditioned by virus producer cells. Given the practical advantages of reduced volume exposures and/or increased virus to cell ratios obtainable with purified precursor populations, gene transfer to variably enriched suspensions of $\mathrm{CD}_{34}{ }^{+}$cells was also evaluated.

\section{Methods}

Cell lines. The amphotropic retroviral packaging cell line GP-AM12 and the ecotropic packaging line GP-E86 (32) were used for generation of helper-free recombinant virus. Both lines were cultured in HXM medium, which is a Dulbecco's modified Eagle's medium (DME; Terry Fox Laboratory Media Preparation Service, Vancouver, BC), supplemented with $10 \%$ heat-inactivated $\left(55^{\circ} \mathrm{C}\right.$ for $\left.30 \mathrm{~min}\right)$ newborn calf serum (Gibco-BRL, Burlington, Ontario), hypoxanthine (15 $\mu \mathrm{g} / \mathrm{ml}$; Sigma Chemical Co., St. Louis, MO), xanthine $(250 \mu \mathrm{g} / \mathrm{ml}$; Sigma Chemical Co.), and mycophenolic acid ( $25 \mu \mathrm{g} / \mathrm{ml}$ ) (Gibco-BRL). For GP-AM 12 cells, hygromycin B $(200 \mu \mathrm{g} / \mathrm{ml}$; Boehringer Mannheim, Mannheim, FRG) was also added to the HXM medium. Where indicated, neo ${ }^{r}$ virus-producing cell lines were maintained in $\mathrm{G} 418(1 \mathrm{mg} /$ $\mathrm{ml}$; Gibco-BRL). All cells were maintained at $37^{\circ} \mathrm{C}$ in an atmosphere of $5 \% \mathrm{CO}_{2}$. M2-10B4 cells, a murine marrow stromal cell line (33), were grown in RPMI medium with $15 \%$ fetal calf serum (FCS).

Retroviral vectors. All experiments utilized a retroviral vector based on JZen1 in which the $3^{\prime}$ LTR enhancer region is derived from the myeloproliferative sarcoma virus (34), obtained from Dr. S. Cory, Walter and Eliza Hall Institute, Melbourne, Australia. To construct JZen-neo, an 854-basepair MluI/Hincll fragment encompassing only the coding region of the neo ${ }^{r}$ gene was isolated from PMCIneo (35), blunted, and inserted into the Hpal site of JZenl by using standard procedures.

Retroviral production. High-titer clones of virus-producer cells were obtained by using a sequential infection strategy. GP-E86 cells were first transfected with a calcium phosphate preparation of JZen-neo. Medium from these cells was then used to infect GP-AM1 2 cells and these were then cloned and individually titred. The highest-titer clone of GP-AM $12\left(\sim 10^{6} / \mathrm{ml}\right)$ was seeded at low density and then repeatedly infected $(\times 6)$ with medium from GP-E86-JZen-neo to obtain an amphotropic producer line yielding titers of $2-5 \times 10^{7}$ neo $^{\mathrm{r}}$ viruses $/ \mathrm{ml}$. Virus-producing lines used in these studies were found to be helper virus-free both by the $\mathrm{S}^{+} \mathrm{L}^{-}$assay (36) and by demonstrating lack of serial transfer of neo ${ }^{r}$ from an infected human cell line to $3 T 3$ cells.

Source of target cells. Leftover cells from diagnostic marrow aspirates or bone marrow transplant harvests, or peripheral blood samples from chronic myelogenous leukemia (CML) patients with elevated numbers of circulating leukemic progenitors were obtained with informed consent. In some experiments, light-density cells were partially purified by centrifugation on either a Percoll $(<1.068 \mathrm{~g} / \mathrm{ml})$ (Pharmacia Canada Ltd., Baie d'Orfe, Quebec) gradient (37) or on Ficoll (1.070 $\mathrm{g} / \mathrm{ml}$ ) (Pharmacia LKB, Bromma, Sweden). Marrow cells enriched $\geq 500$-fold for LTC-initiating cells (LTC-IC), 1-2\% pure, were isolated as previously described by fluorescence-activated cell sorting (FACS) of light-density marrow cells and collection of a fraction characterized by low forward light scatter, low orthogonal light scatter, low HLA-DR expression $\left(\mathrm{DR}^{ \pm}\right)$, and high CD34 expression $\left(\mathrm{CD} 34^{++} ; 37\right)$.
A less highly enriched LTC-IC population, but one providing larger starting numbers of cells (CD34 ${ }^{+}$cells), was obtained from marrow retrieved from vertebral bodies of normal organ donors (provided by Dr. M. Strong and colleagues at the Northwest Tissue Center, Seattle, WA). A light-density ( $\leq 1.068 \mathrm{~g} / \mathrm{ml}$ ) fraction of these cells was obtained by centrifugation on percoll and aliquots then frozen for later use. $\mathrm{CD}^{+} 4^{+}$cells were selected by labeling first with anti-CD34/anti-dextran tetrameric complexes, and then with magnetic dextran particles $(38,39)$. The separation was carried out by passing the cells over a high-gradient magnetic filter $(38,40)$. The resultant population contained $71 \pm 6 \%$ (mean $\pm \mathrm{SD}) \mathrm{CD} 34^{+}$cells.

Target cell infection using producer cell-conditioned medium. Medium conditioned by virus-producer cells was obtained by replacing the medium on near confluent dishes of virus-producer cells, $24 \mathrm{~h}$ before planned infections, with DME plus $10 \%$ newborn calf serum. This medium was removed at the time of infection and filtered through a 0.22- $\mu \mathrm{m}$ low-protein binding filter (Millex-GV, Millipore Corp., Bedford, MA), and the target hematopoietic cells were resuspended in this conditioned medium to which $4 \mu \mathrm{g} / \mathrm{ml}$ polybrene was also added. The cells were then incubated for $2 \mathrm{~h}$ at $37^{\circ} \mathrm{C}$, then centrifuged, and resuspended in LTC medium (see below). Three repeat cycles of this 2-h infection protocol were carried out either over a 24-h period for sorted cells, or once each day for $3 \mathrm{~d}$ for other types of target cells. After the infection procedure was finished, an aliquot was removed for clonogenic assays and the remainder used to initiate LTC as described below.

Various growth factors were used to supplement both the viruscontaining medium and the LTC medium in which the cells were incubated during and between each infection. Human granulocyte colonystimulating factor (G-CSF) and interleukin 3 (IL-3) were derived from partially purified conditioned media from Cos cells that had been transfected in our laboratory with the corresponding cDNAs. These were used at a final concentration of $20 \mathrm{ng} / \mathrm{ml}$ each. Human stem cell factor (SCF or Steel factor; 41, 42) was obtained from Amgen, Inc. (Thousand Oaks, CA) and used at $100 \mathrm{ng} / \mathrm{ml}$.

Clonogenic progenitor assays. Methylcellulose culture assays were performed as previously described (43). Granulocyte/macrophage colony-forming unit (GM-CFU) colonies were scored after 10-14 d of incubation, and large erythroid burst-forming unit (BFU-E) colonies (from primitive BFU-E) were counted in the same cultures after 18-21 d using established criteria (43). In all experiments, control cells were subjected to the same manipulations (with fresh medium replacing the virus-containing conditioned medium) and then plated with or without G418 at the same time as the infected cells. G418 was used at a final concentration of $1.6-1.8 \mathrm{mg} / \mathrm{ml}$ (depending on the lot of G418), which produced no colony growth from uninfected cells. The neor transfer efficiency was calculated as the number of G418-resistant colonies observed divided by the number of colonies obtained without G418, expressed as a percentage.

LTC-IC assays. In general these were carried out as previously described $(44,45)$. Normal marrow cells were seeded onto a near-confluent irradiated layer (in 60-mm dishes) of murine M2-10B4 cells half of which had been engineered to produce human G-CSF and the other half human IL-3 $(45,46)$. Under these conditions these feeders maintain growth factor concentrations of $9 \mathrm{ng} / \mathrm{ml}$ for IL-3 and $>140 \mathrm{ng} / \mathrm{ml}$ for G-CSF. Input cell numbers varied from 8 to $12 \times 10^{6}$ for light-density normal marrow cells, $10^{4}$ for highly purified cells, $5 \times 10^{5}$ for $\mathrm{CD}^{2} 4^{+}$cells, and $5 \times 10^{6}$ for light density CML peripheral blood cells. LTC were then maintained at $33^{\circ} \mathrm{C}$ in a slightly modified alpha medium containing $12.5 \%$ fetal calf serum, $12.5 \%$ horse serum, $10^{-6} \mathrm{M}$ hydrocortisone sodium hemisuccinate, and $10^{-4} \mathrm{M} 2$-mercaptoethanol with weekly half-medium changes and removal of half of the nonadherent (NA) cells. After 5 or 6 wk the NA cells were removed and the adherent layer was trypsinized (47). Both fractions were assayed for total and neor-resistant BFU-E and CFU-GM. The total number of these progenitors assayed at this time is a measure of the number of LTC-IC in the original inoculum (37).

All manipulations involving amphotropic viruses were performed under level 3 containment following Medical Research Council of Canada guidelines. 
Molecular analyses. To demonstrate the presence of a transferred neo $^{r}$ gene, individual colonies from methylcellulose dishes that had not been selected with G418 were analyzed using the polymerase chain reaction (PCR; 48). Single colonies were plucked using drawn out capillary pipettes in a minimum $(\sim 1 \mu \mathrm{l})$ of methylcellulose, then placed in a $50-\mu \mathrm{l}$ lysis buffer (sucrose $0.32 \mathrm{M}$, Tris- $\mathrm{HCl} \mathrm{pH} 7.510 \mathrm{mM}, \mathrm{MgCl}_{2} 5$ $\mathrm{mM}, 1 \%$ Triton X-100). Proteinase $\mathrm{K}$ was added $(1 \mu \mathrm{l}$ of a $10 \mathrm{mg} / \mathrm{ml}$ solution), and the sample was incubated for $1 \mathrm{~h}$ at $50^{\circ} \mathrm{C}$, followed by 10 min at $95^{\circ} \mathrm{C}$. A fraction $(30 \mu \mathrm{l})$ was analyzed in a PCR containing buffer ( $\mathrm{KCl} 50 \mathrm{mM}$, Tris- $\mathrm{HCl} \mathrm{pH} 8.010 \mathrm{mM}, \mathrm{MgCl}_{2} 5 \mathrm{mM}$ ), oligomers (1 $\mu$ mol each), dNTPs ( $200 \mathrm{mM}$ each), and Taq polymerase ( $2 \mathrm{U}$, Gibco-BRL). The reaction was carried out for 30 cycles as previously described (24), and then Southern blotting was performed using standard techniques (49). The oligomers used were Neo-L 5'-CAAGATGGATTGCACGCAGG-3' and Neo-R 3'-CTTGACAAGCGGTCCGAGTT-5'. NA cells from 2-, 4-, and 6-wk-old LTC initiated with $\mathrm{CD} 4^{+}$cells were also analyzed for the presence of the neo ${ }^{\mathrm{r}}$ gene by conventional Southern blotting (49). In these experiments, GM-CSF $(20 \mathrm{ng} / \mathrm{ml})$ was added to the culture medium (every $2 \mathrm{~d}$ ) during the last 2 wk of LTC (weeks 4-6) to enhance NA cell output (45). High molecular weight DNA was extracted from the NA cells, restriction-digested using Xba I (which excised the intact provirus) and Hind III (which cuts once in the provirus, excising a different sized fragment for each clone), and then analyzed using standard Southern blotting techniques with a neo ${ }^{\mathrm{r}}$ specific probe.

Statistical analysis. Results are expressed as means \pm SEM of the data for two or more experiments. Measures of significance for various comparisons were calculated using Student's $t$ test.

\section{Results}

An initial series of experiments were conducted to test the efficiency of gene transfer that could be obtained by using filtered cell-free supernatants containing a high-titer JZen-neo virus to infect low density normal human marrow cells under improved conditions of growth factor stimulation. The choice of growth factors used in this study was based on earlier results with virus producer co-cultivation infection protocols which showed that the addition of G-CSF and IL-3 was the most effective including a comparison to the previous reported combination of GM-CSF, IL- $1 \beta$, and human leukocyte conditioned medium (data not shown; 24). In addition, this choice allowed us to exploit the potential additional advantage of using murine fibroblast cell lines genetically engineered to constitutively produce human G-CSF and IL-3, thus serving as a convenient and highly effective source of growth factors capable of maintaining the continuous cycling of highly proliferative potential clonogenic cells in LTC and in enhancing output of LTC-IC from such cultures $(45,46)$. A viral supernatant infection strategy was thus tested that involved incubation of the cells and virus (supplemented with IL-3 and G-CSF) together for $2 \mathrm{~h}$ (as described in Methods) and then seeding the washed cells on top of a mixture of M2-10B4 cells producing IL-3 and G-CSF $(45,46)$. All NA cells were removed 1 and $2 \mathrm{~d}$ later, resuspended in virus-containing medium (again supplemented with IL-3 and G-CSF), incubated together in suspension for $2 \mathrm{~h}$, and then returned to feeders in fresh LTC medium. In an attempt to further improve conditions in some groups, $100 \mathrm{ng} / \mathrm{ml}$ of Steel factor (SCF [41]) was also added to the LTC and viral conditioned medium during the infection periods based on recent evidence that this factor may have marked stimulatory effects on primitive hemopoietic cells $(50$, 51). At the end of the infection period, an aliquot was removed for clonogenic cell assays, and the remainder left on the M210B4 feeders for LTC-IC assays. As shown in Fig. 1, this protocol resulted in high gene transfer efficiencies to both clonogenic progenitors (48\% and $23 \%$ for GM-CFU and BFU-E, respectively) and LTC-IC (41\%) which are comparable to the best reported efficiencies obtained using a viral cell producer co-cultivation strategy and the addition of exogenous growth factors (24). Additional supplementation of the infection medium with $100 \mathrm{ng} / \mathrm{ml}$ of Steel factor did not result in a significant increase $(P>0.05)$ in efficiencies over that obtained with added IL-3 plus G-CSF alone using this protocol. Endogenous production of Steel factor by M2-10B4 cells has, however, been demonstrated (data not shown) and hence the lack of an additional stimulatory effect on transfer does not exclude a potential action of Steel factor as seen below.

Purified cells. Subsequent experiments were designed to assess gene transfer efficiencies to primitive hematopoietic cells by using a supernatant infection procedure but in the absence of intermittent incubation of the cells on a feeder layer inas-

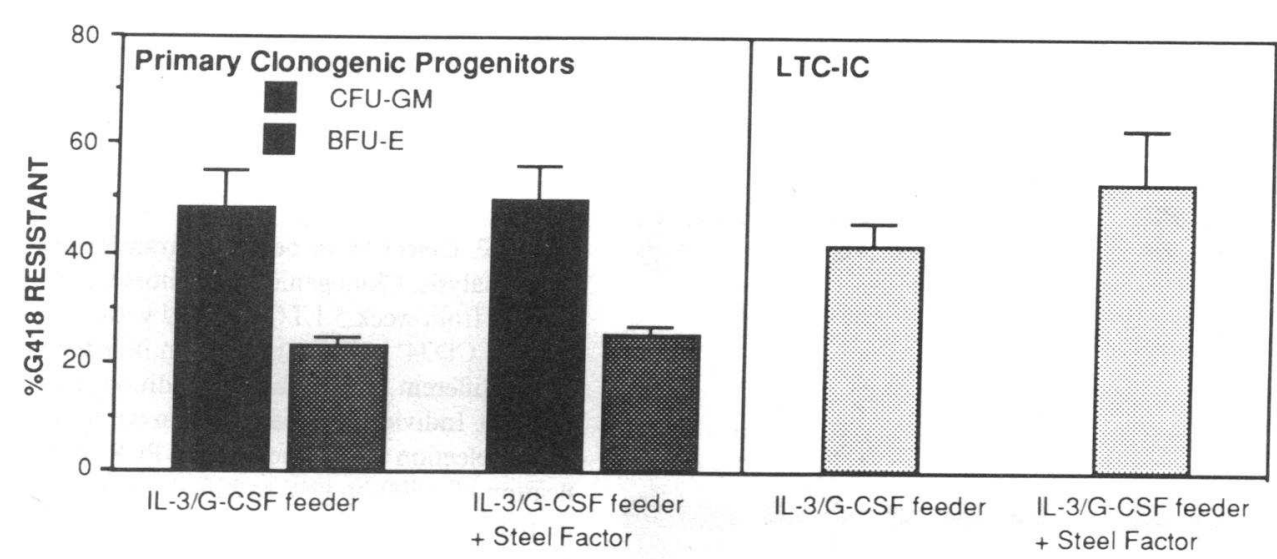

SUPERNANTANT INFECTION CONDITION
Figure 1. Gene transfer to marrow mononuclear cells using a supernatant infection protocol. Marrow mononuclear cells were placed on irradiated murine M2-10B4 cells genetically engineered to produce human IL-3 and G-CSF and exposed to filtered high-titer JZen neo viral supernatants $\left(>10^{7} / \mathrm{ml}\right)$ for 2 $\mathrm{h}$ repeated over $3 \mathrm{~d}$, in polybrene $(4$ $\mu \mathrm{g} / \mathrm{ml})$. Where indicated, exogenous Steel factor was added during the infection period. After infection an aliquot of each culture was assayed for $\mathrm{G} 418^{\mathrm{r}}$ clonogenic progenitors, and the balance maintained as LTC-IC. Relative LTC-IC values were determined from assay of total clonogenic progenitors recovered from 5-wk-old LTC. Shown are the mean \pm SE\% $G 418^{r}$ primary clonogenic progenitors and LTC-IC (three experiments). 
Table I. Gene Transfer to Highly Purified Normal LTC-IC by Supernatant Infection in Short-Term Suspension Culture

\begin{tabular}{lrrr}
\hline & \multicolumn{3}{c}{ Clonogenic progenitors in 5-wk-old LTC } \\
\cline { 2 - 4 } \multicolumn{1}{c}{ Infection conditions } & G418 per total colonies & Percent G418 & Percent neo-positive \\
\hline No growth factor & $348 \pm 121 / 2,417 \pm 363$ & $14 \pm 3(n=2)$ & $3 \pm 3(n=2)$ \\
IL-3 + G-CSF & $675 \pm 204 / 2,414 \pm 543$ & $27 \pm 2(n=3)$ & $43 \pm 6(n=3)$ \\
IL-3 + G-CSF + Steel factor & $1,695 \pm 206 / 2,794 \pm 304$ & $61 \pm 4(n=5)$ & $80 \pm 6(n=3)$
\end{tabular}

Marrow was highly enriched for LTC-IC by FACS and isolation of the CD34 ${ }^{++}$, HLA-DR ${ }^{ \pm}$, low forward light scatter, and low orthogonal light scatter population. For each condition shown $10^{4}$ of these cells were exposed to filtered JZen-neo viral containing supernatants ( 1 ml of virus per $10^{4}$ cells) for 2 -h periods three times over $24 \mathrm{~h}$ in the presence of added soluble growth factors as indicated. Recovered cells were then used to initiate LTC on preestablished M2-10B4 feeders producing human IL-3 and human G-CSF. Gene transfer to LTC-IC was assessed by analysis of clonogenic progenitors recovered from 5-wk-old LTC for G418 colony formation, or detection by PCR of the neo sequence in colonies grown in the absence of G418 ( 10 colonies analyzed per condition). Values shown are the mean per LTC \pm SE for $n$ experiments.

much as this would be unlikely to be a clinically practical procedure. Also, to increase the virus to target cell ratio and to allow a better definition of growth factor effects on transfer efficiencies, we used as target cells a subpopulation of CD34 ${ }^{++}$ normal marrow cells that is highly enriched for LTC-IC (37) and depleted of stromal and mature hematopoietic cells. Small numbers of these purified cells $\left(10^{4}\right.$ per infection condition) were infected over a period of $24 \mathrm{~h}$ by three repeat cycles of exposure to high-titer, filtered, virus-containing supernatants ( $1 \mathrm{ml} / 10^{4}$ cells) for $2 \mathrm{~h}$ followed by resuspension and incubation for $6 \mathrm{~h}$ in LTC medium. Cells were maintained throughout this period (including exposure to virus) under three different conditions: no added growth factors, IL-3 plus G-CSF, or IL-3 plus G-CSF plus Steel factor. At the end of the $24 \mathrm{~h}$, LTC-IC were assayed by seeding the cells onto M2-10B4 feeders producing IL-3 plus G-CSF (45). Measurement of ini- tial infection efficiencies to clonogenic progenitors was not feasible in these experiments because of the small numbers of cells available. Gene transfer efficiencies measured for LTC-IC are summarized in Table I.

Infections performed in the absence of growth factor stimulation resulted in detectable but low gene transfer to LTC-IC $(14 \pm 3 \%)$. Infections performed in the presence of IL-3 plus G-CSF yielded significantly higher gene transfer efficiencies $(27 \pm 2 \% ; P<0.02)$ and a further twofold enhancement in gene transfer was observed with the addition of Steel factor $(61 \pm 4 \%$; $P<0.02$ compared to IL-3 with G-CSF). However, the presence or absence of growth factors during the infection period had no demonstrable effect on clonogenic progenitor recovery after $5 \mathrm{wk}$ indicating that this short-term $(24 \mathrm{~h})$ treatment did not alter LTC-IC plating efficiency or clonogenic cell output.

The level of neo ${ }^{r}$ gene transfer measured by the functional

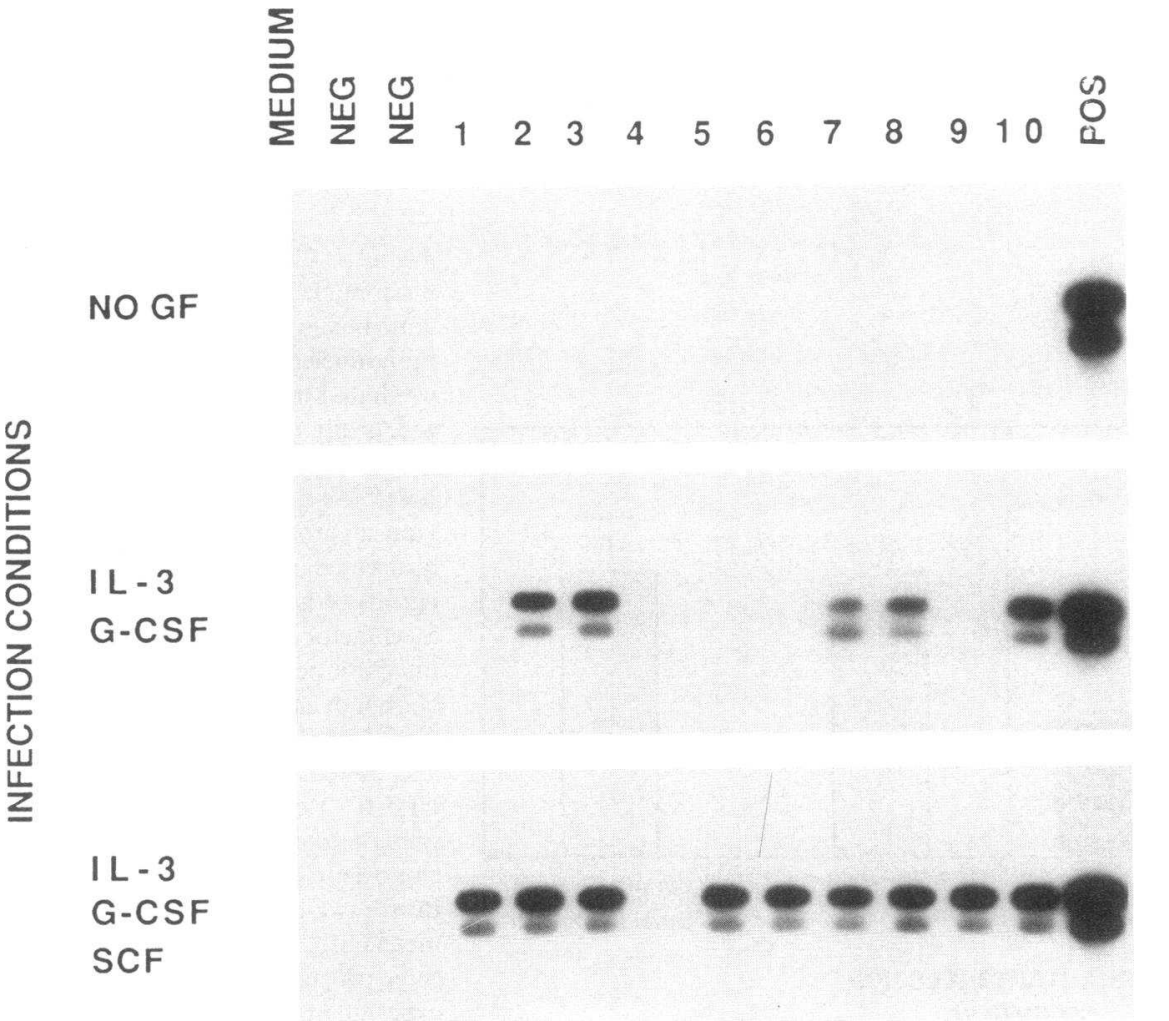

Figure 2. Detection of neo ${ }^{r}$ gene transfer by PCR analysis. Clonogenic progenitors were assayed from week 5 LTC initiated with highly purified $\mathrm{CD} 34^{+}$cells that had been infected under different growth factor conditions (see Table I). Individual colonies grown without G418 selection were plucked and PCR amplification of a 500-bp neor specific fragment was carried out. Southern blot analysis of PCR products from 10 colonies analyzed for each infection condition are shown for a representative experiment. 
assay for G418 colony formation was confirmed by detection of the neo ${ }^{\mathrm{r}}$ gene by PCR analysis of individual colonies grown in the absence of $\mathrm{G} 418$ selection. Fig. 2 shows a representative Southern blot analysis of PCR products from one such experiment. Estimates of the proportion of neo ${ }^{\mathrm{r}}$-positive colonies assessed by PCR are comparable to values obtained by G418-resistant colony formation (Table I), suggesting that with this vector, satisfactory levels of neo ${ }^{\mathrm{r}}$ expression to overcome G418 toxicity are usually achieved.

Bulk purified cells. A next series of experiments were undertaken to determine if high-efficiency gene transfer using a supernatant infection technique could be obtained with a population of $\mathrm{CD} 34^{+}$cells obtainable using a procedure with the potential for application to large-scale clinical marrow harvests (see Methods). In addition, this procedure provided larger numbers of cells thus allowing preselection in $\mathrm{G} 418$ to be evaluated as a potential manipulation together with more detailed molecular analyses. Analogous to the procedure used for highly purified $\mathrm{CD}_{3} 4^{+}$cells, bulk-purified cells $\left(71 \% \mathrm{CD}^{2} 4^{+}\right)$were infected by three repeat cycles of a 2-h exposure to filtered viruscontaining supernatants and then resuspension in LTC medium. In this case infections were performed at daily intervals for $3 \mathrm{~d}$ under two conditions: no growth factor supplementation or continuous exposure (including incubation with viral supernatant) to IL-3, G-CSF, and Steel factor. Cells were then maintained in suspension culture for an additional $48 \mathrm{~h}$ after infection prior to initiation of LTC either with or without added G418 $(1.8 \mathrm{mg} / \mathrm{ml})$. As shown in Fig. 3, high-efficiency gene transfer to clonogenic and LTC-IC was also achieved in these experiments. For both target cell types, efficiencies of $\sim 40 \%$ were obtained when infections were accompanied by growth factor stimulation (significantly higher than efficiencies in the absence of growth factors $P<0.02$ ) and this was further increased in each case by a 48 -h preselection step $(P=0.1)$. Absolute recovery of G418-resistant LTC-IC was not affected by preselection indicating no nonspecific toxicity of this procedure. (After infection in the presence of growth factor, G418resistant LTC-IC/total LTC-IC per culture were 1,448 \pm 105 / $3,474 \pm 72$ without preselection, and $1,444 \pm 14 / 2,483 \pm 217$ with preselection.)

NA cells from these LTC were further analyzed by Southern blot to confirm the presence of the transferred neo ${ }^{\mathrm{r}}$ gene and to assess the clonal derivation of marked cells. Fig. 4 presents results from one such analysis performed on NA cells recovered at 2, 4, and 6 wk after initiation of the LTC. Digestion with $\mathrm{XbaI}$ and hybridization to a probe for neo ${ }^{\mathrm{r}}$ revealed the expected 3.0-kb proviral band at all times tested in cultures that were initiated with cells infected under growth factorstimulated conditions. In contrast, the neo ${ }^{r}$ sequence was not detectable by Southern analysis of NA cells from LTC initiated with cells infected in the absence of growth factors. Digestion of DNA with HindIII to release unique viral integration fragments did not reveal any marked clones in LTC initiated without preselection, whereas one or two unique bands were readily evident in cultures initiated with infected cells that had undergone a preselection step. The difference in intensities of the two unique bands detectable at 4 and 6 wk are suggestive of two marked clones. Comparison of the intensity of these bands with that seen in XbaI digested DNA further suggests that by 4 wk, these two clones had become predominant in the NA neorpositive fraction of this LTC. In contrast, at 2 wk the same clone appears to account for only a minority of the neor-positive population consistent with the presence of many marked clones not detectable as discrete bands. Similar findings of early polyclonal contributions with subsequent emergence of an oligoclonal pattern were obtained in a separate experiment (data not shown).

Leukemic cell targets. For many experimental and potential clinical applications it will be desirable to achieve gene transfer to primitive leukemic stem cells. Recent studies have revealed that in addition to normal LTC-IC a $\mathrm{Ph}^{1}$-positive (leukemic) functional equivalent can also be detected in cells from patients with CML (52). Peripheral blood mononuclear cells from patients with CML with high leukocyte counts provide a highly enriched source of such leukemic LTC-IC essentially free of normal LTC-IC (53). Therefore, to determine if the methods for gene transfer developed above for normal cells could also be applied to analogous primitive CML cells, peripheral blood mononuclear cells from CML patients with elevated leukocyte counts were subjected to repeated $(\times 3)$ supernatant infections as in the previous experiments and then seeded onto M2-10B4 feeders producing IL-3 and G-CSF for LTC-IC assay. Gene transfer efficiencies, both to clonogenic progenitors and LTC-IC, of $\sim 35 \%$ were observed (Table II). As with normal

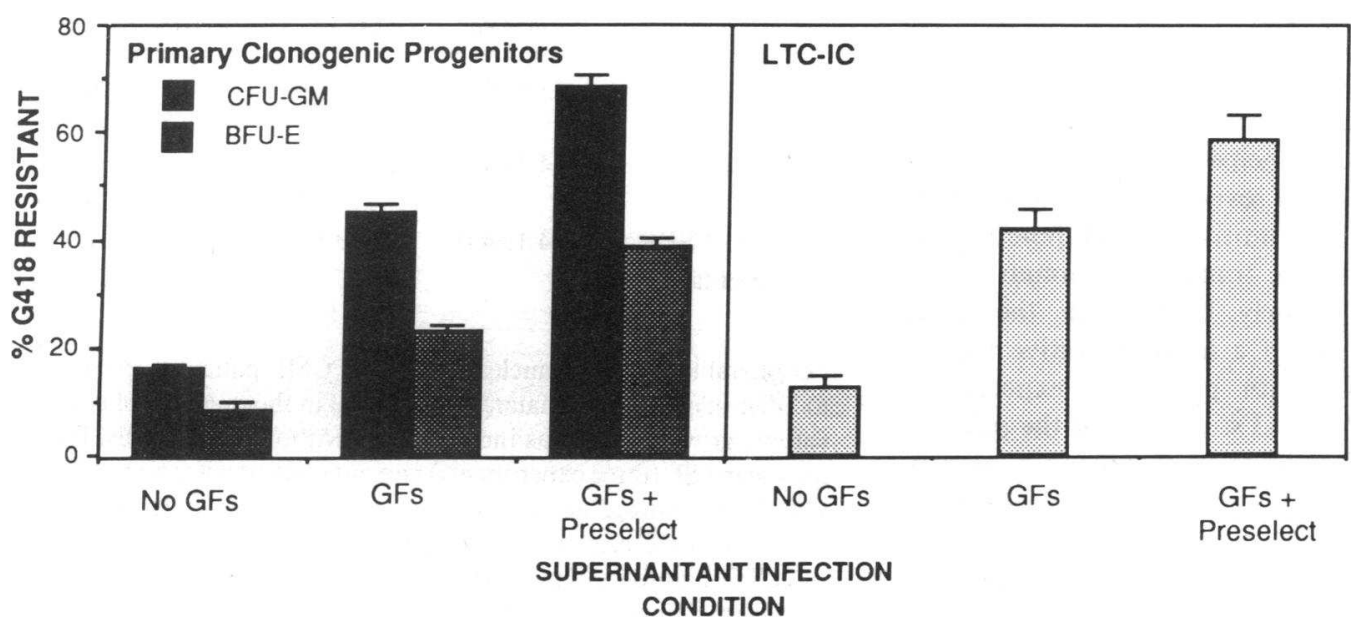

Figure 3. Gene transfer to "bulk purified" CD34 ${ }^{+}$cells. $\mathrm{CD}^{+} 4^{+}$marrow cells were infected with high titre JZenneo viral supernatants under conditions of no growth factor, or growth factor stimulation (IL-3, G-CSF, and Steel factor), on each of three consecutive days without or with subsequent preselection for $48 \mathrm{~h}$ with $\mathrm{G} 418(1.8 \mathrm{mg} / \mathrm{ml})$. Gene transfer efficiencies to primary clonogenic progenitors and LTC-IC were assessed as previously described. Shown are mean \pm SE percent G418 targets for two experiments. 
INFECTION CONDITIONS

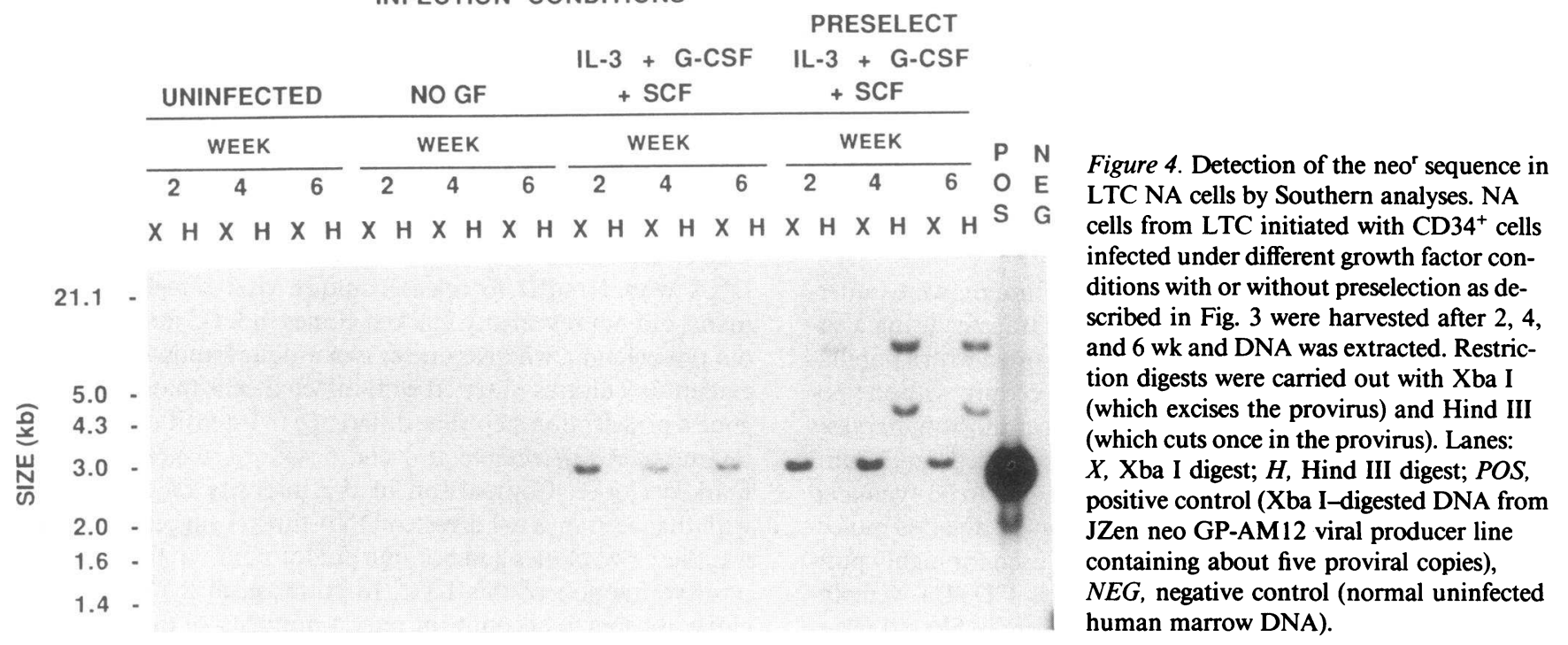

cell targets these efficiencies were significantly enhanced (over threefold; $P<0.02$ ) by stimulation with growth factors during infection. Interestingly, in contrast to results with normal LTCIC infected in the absence of feeder cells (Table I), the addition of Steel factor did not enhance efficiencies over that achieved with IL-3 plus G-CSF. Also, in contrast to findings for normal CD34 ${ }^{+}$LTC-IC, recovery of CML LTC-IC was diminished $(\sim 60 \%)$ in the absence of growth factor stimulation during the infection period $(1,329$ LTC-IC per culture without growth factors during infection vs. 3,081 or 3,514 with growth factor stimulation; $P<0.05$ ).

\section{Discussion}

Retroviral mediated gene transfer is being considered widely as a potential clinical tool for the marking and manipulation of primitive human hematopoietic cells. Although a number of study protocols have been approved to allow investigation of this technique in bone marrow transplant recipients, the data published thus far on retroviral infection of either large animal or human progenitors would not allow one to predict with confidence that marrow repopulating cells could be efficiently infected. Moreover, the technologies employed in many of the studies where high efficiency transfer to human clonogenic progenitors have been previously demonstrated, are not suitable for clinical applications. Nevertheless, improvements in methods for generating high-titer, helper-free recombinant retroviruses and the identification of several growth factors with potent stimulatory effects on primitive hematopoietic cells have allowed high-efficiency gene transfer to human clonogenic cells to be obtained routinely. In addition, the recent development of assays that detect a more primitive type of human progenitor (LTC-IC) with properties expected of marrow repopulating cells (54) and strategies for the purification of these cells $(37,55)$ now allow assessment of gene transfer to more relevant target cells. In this study we show that high-efficiency gene transfer to such cells can now be accomplished using protocols that should be clinically applicable. The use of cell-free virus-conditioned medium for retroviral infection of human marrow cells not only satisfies concerns with regard to the risk of inadvertent contamination of target cells with viral producers, but also potentially enhances the convenience and reproducibility of the infection protocol since such reagents can be titered, tested, and characterized in large quantities and then frozen for future use. The present experiments demonstrate reproducible efficiencies of gene transfer to normal human LTC-IC as high as $60 \%$ regardless of the purity of the target cell population and to CML LTC-IC of 35\%. These efficiencies should be adequate for either marking studies or the introduction of a functional gene for a variety of situations where autologous marrow transplants would be used.

The use of appropriate growth factors during the infection period was clearly necessary to achieve optimal gene transfer efficiencies to clonogenic cells and LTC-IC in all of the human marrow populations tested; i.e., light-density cells, $\mathrm{CD} 34^{+}$

Table II. Gene Transfer to Leukemic Clonogenic Progenitors and LTC-IC in CML Blood

\begin{tabular}{|c|c|c|c|}
\hline \multirow[b]{2}{*}{ Infection condititions } & \multicolumn{2}{|c|}{$\begin{array}{l}\text { Percent G418r clonogenic } \\
\text { progenitors* }\end{array}$} & \multirow{2}{*}{$\begin{array}{l}\text { Percent G418 }{ }^{r} \text { LTC-IC } \\
\text { (G418/Total LTC-IC) }\end{array}$} \\
\hline & CFU-GM & BFU-E & \\
\hline No GF & $13.5 \pm 0.9$ & $6.3 \pm 1.6$ & $\begin{array}{c}7.7 \pm 1.1 \\
(101.3 / 1,329)\end{array}$ \\
\hline $\mathrm{IL}-3$ + G-CSF & $44.3 \pm 4.6$ & $19.6 \pm 1.9$ & $\begin{array}{c}34.7 \pm 2.1 \\
(1,066 / 3,081)\end{array}$ \\
\hline $\begin{array}{l}\text { IL-3 + G-CSF } \\
\text { + Steel factor }\end{array}$ & $44.1 \pm 4.0$ & $22.7 \pm 1.5$ & $\begin{array}{c}35.3 \pm 1.9 \\
(1,240 / 3,514)\end{array}$ \\
\hline
\end{tabular}

Peripheral blood mononuclear cells from CML patients were exposed to JZen-neo viral supernatant daily for $3 \mathrm{~d}$ in the presence of added soluble growth factors as indicated but without feeder cells. Results are mean $\pm S E$ (three experiments) percent gene transfer assessed by G418 . * Clonogenic progenitors assayed immediately after infection. ${ }^{\ddagger}$ LTC-IC assayed by clonogenic progenitor output from 5-wkold LTC. Numbers in parentheses are mean number of G418 $8^{\mathrm{r}} 5$-wk clonogenic progenitors (LTC-IC) over total per LTC. 
cells, and a highly enriched subpopulation of $\mathrm{CD} 34^{+}$cells. These data extend our previous observations on the usefulness of GM-CSF and IL-1 in this regard to include IL-3 plus G-CSF and Steel factor as the optimal growth factor combination thus far identified. Growth factors are thought to enhance retroviral infection efficiencies by promoting cell entry into the $S$ phase. Despite this conventional wisdom, gene transfer to clonogenic progenitors in normal marrow or CML peripheral blood samples, both of which contain predominantly cycling populations, is significantly enhanced by growth factors. In addition, a relatively short exposure of LTC-IC to growth factors, which is not likely to be sufficient to initiate their immediate entry into $S$ phase (56), enables gene transfer to these cells to be increased many-fold. Because the actions of growth factors are known to be pleotropic, this effect may be mediated by the stimulation of some other metabolic cascade, e.g., leading to an up-regulation of cell surface viral receptor. PCR analysis of unselected colonies revealed that the proportion of colonies carrying the integrated gene generally parallels that identified by $\mathrm{G} 418$ resistance. This not only confirms the results of the functional assay but indicates that low G418-resistant efficiencies, at least in this system, are the result of a deficiency at the infection-integration stage rather than a failure of expression. Efforts to improve infection further are, therefore, likely to continue to be fruitful.

The LTC-IC assay allows detection of the most primitive human progenitor that can currently be identified in vitro. However, the relationship of these cells to those with short and long-term marrow repopulating ability is not yet established. The ability to both highly purify and efficiently mark LTC-IC now makes the identification and tracking of their progeny in vivo a practical possibility. Our demonstration of retroviral marking of progenitors with sufficient proliferative capacity to dominate the LTC system after 4-6 wk in culture indicates that further investigation of LTC-IC dynamics in vitro using this approach is also possible. By such combined in vitro studies and assessment of clinical transplants, it should therefore soon be possible to define the functional potential of cells now measured by quantitative in vitro procedures.

\section{Acknowledgments}

We thank Dr. A. Banks (Columbia University, New York, NY) for providing viral packaging cell lines; Dr. Khris Zsebo of Amgen, Inc., for providing human stem cell factor; and Dr. M. Strong of the Northwest Tissue Center for organ donor marrow samples. The expert technical assistance of Patricia Rosten and secretarial support of Karen Windham is gratefully acknowledged.

This work was supported by an operating grant from the National Cancer Institute of Canada (NCIC). P. F. D. Hughes was an NCIC Terry Fox Fellow, and C. J. Eaves is a Terry Fox Cancer Research Scientist of NCIC.

\section{References}

1. Karlsson, S. 1991. Treatment of genetic defects in hematopoietic cell function by gene transfer. Blood. 78:2481-2492.

2. Szilvassy, S. J., C. C. Fraser, C. J. Eaves, P. M. Lansdorp, A. C. Eaves, and R. K. Humphries. 1989. Retrovirus-mediated gene transfer to purified hemopoietic stem cells with long-term lympho-myelopoietic repopulating ability. Proc. Natl. Acad. Sci. USA. 86:8798-8802.

3. Fraser, C. C., C. J. Eaves, S. J. Szilvassy, and R. K. Humphries. 1990. Expansion in vitro of retrovirally marked totipotent hematopoietic stem cells. Blood. 76:1071-1076.

4. Capel, B., R. G. Hawley, and B. Mintz. 1990. Long- and short-lived clones individually identified with retroviral integration markers. Blood. 75:2267-2270.
5. Van Zant, G., J.-J. Chen, and K. Scott-Micus. 1991. Developmental potential of hematopoietic stem cells determined using retrovirally marked allophenic marrow. Blood. 77:756-763.

6. Bodine, D. M., K. T. McDonagh, N. E. Seidel, and A. W. Nienhuis. 1991 Survival of retroviral infection of murine hematopoietic stem cells in vitro: effects of 5-FU and method of infection. Exp. Hematol. 19:206-212.

7. Fraser, C. C., S. J. Szilvassy, C. J. Eaves, and R. K. Humphries. 1992. Proliferation of totipotent hematopoietic stem cells in vitro with retention of long-term competitive in vivo reconstituting ability. Proc. Natl. Acad. Sci. USA. 89:1968-1972.

8. Lemischka, I. R. D. H. Raulet, and R. C. Mulligan. 1986. Developmental potential and dynamic behavior of hematopoietic stem cells. Cell. 45:917-927.

9. Snodgrass, R., and G. Keller. 1987. Clonal fluctuation within the haematopoietic system of mice reconstituted with retrovirus-infected stem cells. $E M B O$ (Eur. Mol. Biol. Organ.) J. 6:3955-3960. 278.

10. Miller, A. D. 1990. Progress toward human gene therapy. Blood. 76:271-

11. Apperley, J. F., B. D. Luskey, and D. A. Williams. 1991. Retroviral gene transfer of human adenosine deaminase in murine hematopoietic cells: effect of selectable marker sequences on long-term expression. Blood. 78:310-317.

12. Kwok, W. W., F. Schuening, R. B. Stead, and A. D. Miller. 1986. Retroviral transfer of genes into canine hemopoietic progenitor cells in culture: a model for human gene therapy. Proc. Natl. Acad. Sci. USA. 83:4552-4555.

13. Eglitis, M. A., P. W. Kantoff, J. D. Jolly, J. B. Jones, W. F. Anderson, and C. D. Lothrop. 1988. Gene transfer into hematopoietic progenitor cells from normal and cyclic hematopoietic dogs using retroviral vectors. Blood. 71:717722.

14. Stead, R. B., W. W. Kwok, R. Storb, and A. D. Miller. 1988. Canine model for gene therapy: inefficient gene expression in dogs reconstituted with autologous marrow infected with retroviral vectors. Blood. 71:742-747.

15. Schuening, F. G., R. Storb, R. B. Stead, S. Goehle, R. Nash, and A. D. Miller. 1989. Improved retroviral transfer of genes into canine hematopoietic progenitor cells kept in long-term marrow culture. Blood. 74:152-155.

16. Kantoff, P. W., A. W. Flake, M. A. Eglitis, S. Scharf, S. Bond, E. Gilboa, H. Erlich, M. R. Harrison, E. D. Zanjani, and W. F. Anderson. 1989. In utero gene transfer and expression: a sheep transplantation model. Blood. 73:10661073.

17. Kantoff, P. W., A. P. Gillio, J. R. McLachlin, C. Bordignon, M. A. Eglitis, N. A. Kernan, R. C. Moen, D. B. Kohn, S-F. Yu, E. Karson, S. Karlsson, et al. 1987. Expression of human adenosine deaminase in nonhuman primates after retrovirus-mediated gene transfer. J. Exp. Med. 166:219-234.

18. Bodine, D. M., K. T. McDonagh, S. J. Brandt, P. A. Ney, B. Agricola, E. Byrne, and A. W. Nienhuis. 1990. Development of a high-titer retrovirus producer cell line capable of gene transfer into rhesus monkey hematopoietic stem cells. Proc. Natl. Acad. Sci. USA. 87:3738-3742.

19. Hogge, D. E., and R. K. Humphries. 1987. Gene transfer to primary normal and malignant human hemopoietic progenitors using recombinant retroviruses. Blood. 69:611-617.

20. Hock, R. A., and A. D. Miller. 1986. Retrovirus-mediated transfer and expression of drug resistance genes in human haematopoietic progenitor cells. Nature (Lond.). 320:275-277.

21. Laneuville, P., W. Chang, S. Kamel-Reid, A. A. Fauser, and J. E. Dick. 1988. High-efficiency gene transfer and expression in normal human hematopoietic cells with retrovirus vectors. Blood. 78:624-634.

22. Bayever, E., K. Haines, S. Duprey, E. Rappaport, S. D. Douglas, and S. Surrey. 1988. Protection of uninfected human bone marrow cells in long term culture from G418 toxicity after retroviral-medated transfer of the NEO gene. Exp. Cell Res., 179:168.

23. Bordignon, C., S-F. Yu, C. A. Smith, P. Hantzopoulos, G. E. Ungers, C. A. Keever, R. J. O'Reilly, and E. Gilboa. 1989. Retroviral vector-mediated high-efficiency expression of adenosine deaminase (ADA) in hematopoietic long-term cultures of ADA-deficient marrow cells. Proc. Natl. Acad. Sci. USA. 86:67486752.

24. Hughes, P. F. D., C. J. Eaves, D. E. Hogge, and R. K. Humphries. 1989. High-efficiency gene transfer to human hematopoietic cells maintained in longterm marrow culture. Blood. 74:1915-1922.

25. Dick, J. E., S. Kamel-Ried, B. Murdoch, and M. Doedens. 1991. Gene transfer into normal human hematopoietic cells using in vitro and in vivo assays. Blood. 78:624-634.

26. Holland, C. A., L. Rothstein, M. A. Sakakeeny, P. Anklesaria, J. D. Griffin, K. Harigaya, P. E. Newburger, and J. S. Greenberger. 1989. Infection of hematopoietic and stromal cells in human continuous bonemarrow cultures by a retroviral vector containing the neomycin resistance gene. Acta. Haematol. 82:136-143.

27. Eglitis, M. A., D. B. Kohn, R. C. Moen, R. M. Blaese, and W. F. Anderson. 1988. Infection of human hematopoietic progenitor cells using a retroviral vector with a xenotropic pseudotype. Biochem. Biophys. Res. Commun. 151:201-206.

28. Bodine, D. M., S. Karlsson, and A. W. Nienhuis. 1989. Combination of interleukins 3 and 6 preserves stem cell function in culture and enhances retrovi- 
rus-mediated gene transfer into hematopoietic stem cells. Proc. Natl. Acad. Sci. USA. 86:8897-8901.

29. Fletcher, F. A., D. E. Williams, C. Maliszewski, D. Anderson, M. Rives, and J. W. Belmont. 1990. Murine leukemia inhibitory factor enhances retroviralvector infection efficiency of hematopoietic progenitors. Blood. 76:1098-1103.

30. Kerk, D. K., E. A. Henry, A. C. Eaves, and C. J. Eaves. 1985. Two classes of primitive pluripotent hemopoietic progenitor cells: separation by adherence. $J$. Cell. Physiol. 125:127-134.

31. Mauch, P., J. S. Greenberger, L. Botnik, E. Hannon, and S. Hellman. 1980. Evidence for structured variation in self-renewal capacity within long-term bone marrow cultures. Proc. Natl. Acad. Sci. USA. 77:2927-2930.

32. Markowitz, D., S. Goff, and A. Bank. 1988. A safe packaging line for gene transfer: Separating viral genes on two different plasmids. J. Virol. 62:1120-1124.

33. Lemoine, F. M., R. K. Humphries, S. D. M. Abraham, G. Krystal, and C. J. Eaves. 1988. Partial characterization of a novel stromal cell-derived pre-Bcell growth factor active on normal and immortalized pre-B cells. Exp. Hematol. 16:718-726.

34. Johnson, G. R., T. J. Gonda, D. Metcalf, I. K. Hariharan, and S. Cory. 1989. A lethal myeloproliferative syndrome in mice transplanted with bone marrow cells infected with a retrovirus expressing granulocyte-macrophage colony stimulating factor. EMBO (Eur. Mol. Biol. Organ.) J. 8:441-448.

35. Thomas, K. R., and M. R. Capecchi. 1987. Site-directed mutagenesis by gene targeting in mouse embryo-derived stem cells. Cell. 51:503-512.

36. Miller, A. D., M.-F. Law, and I. M. Verma. 1985. Generation of helperfree amphotropic retroviruses that transduce a dominant-acting, methotrexateresistant dihydrofolate reductase gene. Mol. Cell. Biol. 5:431-437.

37. Sutherland, H. J., C. J. Eaves, A. C. Eaves, W. Dragowska, and P. M. Lansdorp. 1989. Characterization and partial purification of human marrow cells capable of initiating long-term hematopoiesis in vitro. Blood. 74:1563-1570.

38. Thomas, T. E., and P. M. Lansdorp. Purification of CD34 positive cells from human bone marrow using high gradient magnetic separation. In Third International Symposium on Bone Marrow Purging and Processing. S. Gross, A Gee, and D. Worthington-White, editors. John Wiley \& Sons, Inc., New York. In press.

39. Molday, R. S., and D. MacKenzie. 1982. Immunospecific ferromagnetic iron dextra reagents for the labelling and magnetic separation of cells. J. Im munol. Methods. 52:353-367.

40. Miltenyi, S., W. Muller, W. Weichel, and A. Radbruch. 1990. High gradient magnetic cell separation with MACS. Cytometry. 11:231-238.

41. Martin, F. H., S. V. Suggs, K. E. Langley, H. S. Lu, J. Ting, K. H. Okino, C. F. Morris, I. K. McNiece, F. W. Jacobsen, E. A. Mendiaz, et al. 1990. Primary structure and functional expression of rat and human stem cell factor DNAs. Cell. 63:203-211.

42. Zsebo, K. M., J. Wypych, I. K. McNiece, H. S. Lu, K. A. Smith, S. B Karkare, R. K. Sachdev, V. N. Yuschenkoff, N. C. Birkett, L. R. Williams, et al. 1990. Identification, purification, and biological characterization of hematopoietic stem cell factor from buffalo rat liver-conditioned medium. Cell. 63:195201.
43. Eaves, C. J., and A. C. Eaves. 1978. Erythropoietin (Ep) dose-response curves for three classes of erythroid progenitors in normal human marrow and in patients with polycythemia vera. Blood. 52:1196-1210.

44. Sutherland, H. J., P. M. Lansdorp, D. H. Henkelman, A. C. Eaves, and C. J. Eaves. 1990. Functional characterization of individual human hematopoietic stem cells cultured at limiting dilution on supportive marrow stromal layers. Proc. Natl. Acad. Sci. USA. 87:3584-3588.

45. Sutherland, H. J., C. J. Eaves, P. M. Lansdorp, J. D. Thacker, and D. E. Hogge. 1991. Differential regulation of primitive human hematopoietic cells in long-term cultures maintained on genetically engineered murine stromal cells. Blood. 78:666-672.

46. Otsuka, T., J. D. Thacker, C. J. Eaves, and D. E. Hogge. 1991. Differential effects of microenvironmentally presented interleukin 3 versus soluble growth factor on primitive human hematopoietic cells. J. Clin. Invest. 88:417-422.

47. Coulombel, L., A. C. Eaves, and C. J. Eaves. 1983. Enzymatic treatment of long-term human marrow cultures reveals the preferential location of primitive hemopoietic progenitors in the adherent layer. Blood. 62:291-297.

48. Saiki, R. K., S. Scharf, F. Faloona, K. B. Mullis, G. T. Horn, H. A. Erlich, and N. Arnheim. 1985. Enzymatic amplification of $\beta$-globulin genomic sequences and restriction site analysis for diagnosis of sickle cell anemia. Science (Wash. DC). 230:1351.

49. Maniatis, T., E. F. Fritsch, and J. Sambrook. 1982. Molecular Cloning: A Laboratory Manual. Cold Spring Harbor Laboratory, Cold Spring Harbor, NY.

50. Carow, C. E., G. Hangoc, S. H. Cooper, D. E. Williams, and H. E. Broxmeyer. 1991. Mast cell growth factor (c-kit ligand) supports the growth of human multipotential progenitor cells with a high replating potential. Blood. 78:22162221

51. Migliaccio, G., A. R. Migliaccio, J. Valinsky, K. Langley, K. Zsebo, J. W. M. Visser, and J. W. Adamson. 1991. Stem cell factor induces proliferation and differentiation of highly enriched murine hematopoietic cells. Proc. Natl. Acad. Sci. USA. 88:7420-7424.

52. Udomsakdi, C. C. J. Eaves, B. Swolin, D. E. Reid, and A. C. Eaves. 1991 Primitive chronic myeloid leukemia (CML) cells exhibit defective self-maintenance in long-term culture without dimunition of their clonogenic cell output. Blood. 78(Suppl. 1):29a. (Abstr.)

53. Eaves, A. C., J. D. Cashman, L. A. Gaboury, D. K. Kalousek, and C. J. Eaves. 1986. Unregulated proliferation of primitive chronic myeloid leukemia progenitors in the presence of normal marrow adherent cells. Proc. Natl. Acad. Sci. USA. 83:5306-5310.

54. Eaves, C. J., H. J. Sutherland, C. Udomsakdi, P. M. Lansdorp, S. J. Szilvassy, C. C. Fraser, R. K. Humphries, M. J. Barnett, G. L. Phillips, and A. C. Eaves. The human hematopoietic stem cell in vitro and in vivo. Blood Cells. In press.

55. Lansdorp, P. M., H. J. Sutherland, and C. J. Eaves. 1990. Selective expression of CD45 isoforms on functional subpopulations of CD34+ hemopoietic cells from human bone marrow. J. Exp. Med. 172:363-366.

56. Ogawa, M., K. Ikebuchi, and A. G. Leary. 1989. Humoral regulation of stem cell proliferation. Ann. N. Y. Acad. Sci. 554:185-191. 